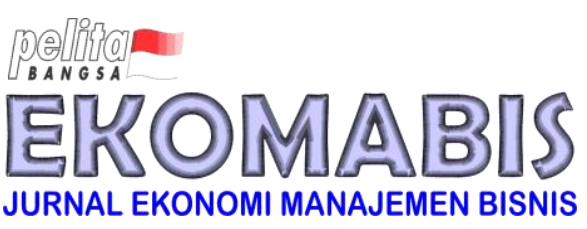

\title{
Profitabilitas Sebagai Mediasi Struktur Modal dan Pertumbuhan Perusahaan Terhadap Return Saham Syariah
}

\section{(Profitability as a Mediation of Capital Structure and Company Growth on Sharia Stock Return)}

\section{Vina Marlisa'; Suminar2; Tunggu Ariana ${ }^{3}$; Deska Lafairi Rera4; Ratnasari ${ }^{5}$}

\begin{abstract}
Abstrak
Pasar modal syariah memiliki peran penting pada sektor keuangan. Jakarta Islamic Index (JII) memiliki tingkatan kinerja lebih baik dibandingkan dengan indeks harga saham lainnya. Hal ini membuka peluang bagi investor untuk berinvestasi pada saham-saham syariah untuk meningkatkan return. Penelitian untuk menganalisis profitabiltias (ROE) sebagai mediasi pengaruh struktur modal (DER) dan tingkat pertumbuhan perusahaan (Growth) terhadap return saham syariah. Data dari empat belas perusahaan Jakarta Islamic Index (JII) selama periode tahun 2017-2019 dengan metode purposive sampling dianalisis menggunakan model struktural. Profitabilitas memediasi struktur modal terhadap return saham dimana profitabilitas dipengaruhi secara positif oleh struktur modal dan mempengaruhi return saham secara negatif. Profitabilitas tidak sebagai pemediasi karena pertumbuhan aset tidak mempengaruhi laba perusahaan.
\end{abstract}

Kata Kunci: Profitabilitas, Pertumbuhan Perusahaan, Struktur Modal, dan Return Saham

\section{Abstract}

The syariah capital market has an important role in the financial sector. The Jakarta Islamic Index (JII) which has a better level of performance compared to other stock price indexes. This opens up opportunities for investors to invest in Islamic stocks to increase returns. Research to analyze profitabiltias (ROE) as mediation of the influence of capital structure (DER) and the growth rate of companies (Growth) on the return of Sharia stocks.. The research data was

1 "Prodi Magister Manajemen Universitas Pelita Bangsa"; vmarlisa1606@gmail.com

2 "Prodi Magister Manajemen Universitas Pelita Bangsa"; minararjaya@gmail.com

3 "Prodi Magister Manajemen Universitas Pelita Bangsa"; antunggu@gmail.com

4 "Prodi Magister Manajemen Universitas Pelita Bangsa"; deskalafairi@gmail.com

5 "Prodi Magister Manajemen Universitas Pelita Bangsa"; ratna.roybian01@gmail.com 
obtained from fourteen companies listed on the Jakarta Islamic Index (JII) during the period 2017-2019 with the purposive sampling method analyzed using a structural model. Profitability mediates capital structure on stock returns where profitability is positively influenced by capital structure and negatively affects stock returns. Profitability is not a mediator because asset growth does not affect the company's profit.

Keywords: Profitability, Company Growth ,Capital Structure, and Stock Return Code JEL:

\section{Pendahuluan}

Pasar modal merupakan sarana perdagangan berbagai jenis instrument keuangan dalam jangka panjang (Pandaya et al., 2020), termasuk pasar modal Syariah yang juga memiliki peran penting dalam sektor keuangan. Akhir tahun 2007 kinerja saham Syariah di Jakarta Islamic Index (JII) memiliki level lebih baik dibandingkan indeks harga saham lainnya (Lilik dan AK, 2010). Setiap investor perlu memiliki rencana untuk menjaga nilai investasinyaa dengan mempertimbangkan tingkat risiko dan pengembalian yang seimbang dalam setiap transaksinya. Semakin tinggi tingkat pengembalian suatu investasi akan selalu menjanjikan return yang pasti bagi investor (Widodo, 2007, Eduardus Tandelilin, 2010). Kinerja perusahaan dapat dinilai berdasar prospek hasil yang akan diperoleh perusahaan sehingga pada saat investor memutuskan untuk berinvestasi dapat meningkatkan harapannya memperoleh return yang besar dengan tingkat keuntungan yang paling kecil risikonya (Trisnawati, 2009).

Kapitalisasi pasar saham syariah periode 2017-2019 mengalami pergerakan yang kurang stabil. Tahun 2017 sebesar 3.704,54; mengalami penurunan 3.666,68 di tahun 2018 dan tahun 2019 meningkat menjadi 3.744,81. Bertambahnya jumlah saham syariah juga memicu peningkatan investor untuk berinvestasi (IDX SYARIAH, n.d.).

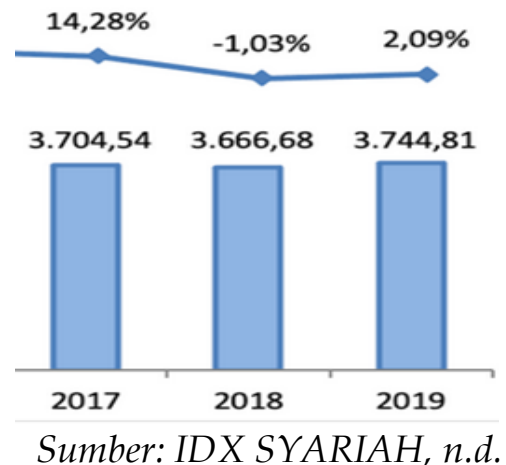

Gambar 1. Kapitalisasi Pasar ISSI 2017-2019

Nilai perusahaan atau prestasi manajemen suatu perusahaan tercermin dari nilai sahamnya. Harga saham tinggi maka nilai perusahaan semakin baik sehingga akan meningkatkan return saham, begitu pula sebaliknya (Pandaya et al., 2020). Return saham adalah selisih harga jual dibandingkan harga beli. Ketika harga jual saham lebih tinggi dari harga belinya, return juga semakin tinggi begitu pula dengan resiko yang dihadapi investor juga akan semakin tinggi (Arista, 2016) (Pandaya et al., 2020). Raturn atau keuntungan atau laba saham yang dimiliki investor dihitung saham berdasar selisih 
harga saham pada periode sekarang dengan sebelumnya (Fitriana et al., 2016). Kelompok saham syariah juga tidak luput dari resiko investasi (Widodo, 2007).

Return saham sangat penting sebagai ukuran kinerja (Purwanti \& Nurastuti, 2020), sehingga perusahaan cenderung berusaha mempertahankan dan meningkatkan kinerjanya agar portofolio saham meningkat. Informasi keuangan dan pasar perusahaan merupakan dua prediktor return saham (Widodo, 2007). Informasi tersebut dapat berupa posisi struktur modal (Solechan \& Setiawati, 2009; Natarsyah, 2000; Sugiarto, 2012; Sugiarto, 2012) dan pertumbuhan perusahaan (Aini et al., 2020).

Struktur modal sebagai perbandingan penggunaan modal asing dengan modal sendiri, penting sebagai ukuran kinerja perusahaan. Modal asing berupa hutang jangka panjang dan pendek sedangkan modal sendiri berupa penyertaan dan atau bersumber dari laba ditahan. Penentuan struktur modal yang optimal menjadi fokus penting pada posisi finansial perusahaan (Mariani et al., 2016). Struktur modal yang diproksi Debt to Equity Ratio (DER) dihitung dengan membagi total hutang dengan modal sendiri. Semakin tinggi hutang dari modal sendiri menunjukkan aktivitas operasional perusahaan lebih banyak bersumber dari hutang sehingga beban untuk membayar hutang beserta bunga juga akan semakin besar. Kondisi tersebut akan menjadi sinyal negatif terjadinya saham dengan harga turun yang berujung pada berkurangnya nilai return saham (Solechan \& Setiawati, 2009; Sugiarto, 2012; Asmirantho et al., 2016).

DER tidak selalu berdampak negatif terhadap return saham karena dapat juga berpengaruh positif, yang menunjukkan bahwa dengan meningkatnya debt ratio (DER) maka harga saham cenderung naik sehingga menghasilkan return saham yang positif. Hal ini sejalan dengan teori dimana struktur modal tidak relevan mempengaruhi nilai perusahaan (Franco \& Merton, 1958). Perusahaan yang menggunakan lebih banyak hutang justru lebih baik (Natarsyah, 2000).

Pertumbuhan perusahaan tercermin dari pertumbuhan aset yaitu presentasi perubahan aset pada tahun sekarang dengan sebelumnya (Aini et al., 2020). Pertumbuhan aset menggambarkan profitabilitas dan pertumbuhan masa depan. Peningkatan aset dan hasil operasi perusahan dapat menambah kepercayaan investor terhadap perusahaan sehinga sangat diharapkan pihak internal dan eksternal. Pertumbuhan bagi investor merupakan tanda perusahaan memiliki prospek sehingga tingkat pengembalian (return) investasi yang dilakukan diharapkan lebih baik.

Penelitian sebelumnya (Solechan \& Setiawati, 2009; Sugiarto, 2012; Asmirantho et al., 2016; Natarsyah, 2000; Aini et al., 2020) menunjukkan adanya pengaruh DER dan pertumbuhan terhadap return saham. Namun, tidak sedikit juga penelitian terdahulu yang menemukan bahwa baik struktur modal (Pranata dkk, 2013; Indah Puspitadewi \& Rahyuda, 2016; Pandaya et al., 2020; Firdausia, 2021) maupun pertumbuhan perusahaan (Komparatif et al., 2006; (Nurkharomi et al., 2017) justru tidak mempengaruhi nilai return saham. Posisi hutang dan pertumbuhan perusahaan tidak selalu menjadi tolak ukur investor karena ada pertimbangan pengelolaan dana oleh manajemen (Pandaya et al., 2020). Hal ini menjadi dasar peneliti untuk menambahkan profitabilitas sebagai faktor yang memediasi struktur modal dan pertumbuhan terhadap return saham (Dwi et al., 2009; Mariani et al., 2016).

Ukuran kemampuan menghasilkan laba dari perusahaan selama periode tertentu adalah bentuk profitabilitas. Kemampuan ini menjadi indikator efektifitas kinerja pengelolaan aset perusahaan oleh pihak manajeme (Dwi et al., 2009). Return on equity 
(ROE) yaitu perbandingan laba bersih dengan ekuitas, disebut juga rentabilitas modal sendiri yang juga ukuran profitabilitas. ROE yang tinggi sangat diharapkan karena dapat menarik perhatian investor. Keuntungan perusahaan meningkatkan permintaan saham, mendorong kenaikan harga saham dan akhirnya return saham meningkat (Dwi et al., 2009; Carlo, 2014; Mariani et al., 2016).

Penentuan struktur modal yang optimal bertujuan untuk memaksimalkan hasil operasi perusahaan yang dibuktikan berdasarkan laba yang dihasilkan (Mariani et al., 2016). ROE yang tinggi mengurangi penggunaan dana eksternal karena perusahaan dengan profitabilitas tinggi mampu menghasilkan atau menyediakan dana internal yang besar untuk mendanai aktivitas operasional perusahaan sehingga dapat menurunkan penggunaan akan dana eksternal dan akhirnya mempenguhi posisi struktur modal (Wiyani, 2017; Mariani et al., 2016). Profitabilitas juga dimanfaatkan perusahaan untuk mempercepat pertumbuhan bisnis dengan membatasi dividen dalam bentuk laba ditahan untuk disimpan sebagai dana investasi pertumbuhan (Cyrus et al., 2001; Jason et al., 2005; Susana \& Achyani Fatchan, 2006; Estika, 2013). Penelitian ini bertujuan menguji peranan profitabilitas sebagai pemediasi struktur modal dan pertumbuhan terhadap return saham.

\section{Metodologi}

\subsection{Pengembangan Model/Konsep}

\subsubsection{Return Saham}

Selisih harga saham yang diterima dan yang diinvestasikan adalah return saham (Eugene \& Houston F Joel, 2009). Return saham dinyatakan dalam persentase yaitu selisih harga dibagi modal awal investasi. Return saham positif atau untung disebut capital gain dan capital loss sebaliknya yaitu return saham negatif atau rugi (Samsul, 2006).

\subsubsection{Profitabilitas dan Return Saham}

Profitabilitas menunjukkan kemampulabaan perusahaan dalam periode waktu, tingkat penjualan, aset, dan ekuitas tertentu (Kasmir, 2011). Return on equity (ROE) sebagai ukuran kemampuan dari perusahaan untuk menghasilkan laba merupakan rasio profitabilitas. ROE adalah laba bersih setelah pajak dibagi total ekuitas. Perusahaan yang mampu menciptakan keuntungan tinggi bagi pemegang saham memiliki ROE tinggi. Perusahaan dengan laba tinggi mengalami kenaikan permintaan sehingga mendorong naiknya harga saham dan berimbas pada peningkatan pengembalian investasi saham. ROE yang tinggi menurunkan penggunaan dana eksternal karena dana internal yang berasal dari laba menjadi lebih besar (Mariani et al., 2016). Kemampuan perusahaan menghasilkan laba berpengaruh positif pada return saham (Michael \& Pizzica, 2014).

\section{H1: Profitabilitas Berpengaruh Positif Terhadap Return Saham}

\subsubsection{Struktur Modal, Profitabilitas dan Return Saham}

Perbandingan hutang dan ekuitas perusahaan disebut struktur modal. Stabilitas keuangan perusahaan bergantung pada sumber dana dan jenis aset perusahaan (Subramanyam \& John, 2014). Struktur modal meunjukkan keseimbangan modal asing 
(hutang) dan modal milik sendiri (laba ditahan atau kepemilikan perusahaan). Semakin besar struktur modal, semakin besar pula risiko akibat semakin banyak biaya utang untuk menjalankan usaha. Struktur modal tercermin dalam debt to equity ratio (DER) yaitu besar modal sendiri digunakan untuk memenuhi kewajiban. Risiko perusahaan akan semakin tinggi ketika hutang tinggi, sebaliknya semakin rendah hutang maka risiko semakin rendah. Laba yang tinggi akan meningkatkan permintaan saham sehingga berdampak pada meningkatnya harga saham (Agus, 2010). Struktur modal yang tinggi dimana penggunaan hutang melebihi modal sendiri menurunkan laba atau profitabilitas (Aprillia \& Mohammad, 2020).

H2: Struktur modal berpengaruh negatif terhadap profitabilitas.

H3: Struktur modal berpengaruh negatif terhadap return saham melalui profitabilitas.

\subsubsection{Pertumbuhan Perusahaan, Profitabilitas dan Return Saham.}

Pertumbuhan perusahaan menunjukkan bertambah atau berkurangnya total aset perusahaan. Pertumbuhan perusahaan menunjukkan persentase perubahan (naik atau turun) aset tahun tertentu relatif terhadap tahun sebelumnya (Rr, 2011). Pertumbuhan perusahaan berkorelasi positif dengan keputusan pendanaan. Semakin tinggi pertumbuhan menunjukkan semakin besar peluang ekspansi (Eugene \& Houston F Joel, 2009). Pertumbuhan perusahaan menggambarkan penggunaan dana untuk operasional dan investasi. Aset likuid maupun jangka bisa berasal dari pendanaan internal atau eksternal (JONI \& LINA, 2010). Aset yang meningkat membuat potensi keuntungan menjadi semakin besar (Eni, 2016) sehingga meningkatkan harga saham (Agus, 2010)

H4: Pertumbuhan perusahaan berpengaruh positif terhadap profitabilitas.

H5: Pertumbuhan Perusahaan berpengaruh positif terhadap return saham melalui profitabilitas.

Tabel 2. Operasional Variabel

\begin{tabular}{ll}
\hline \multicolumn{1}{c}{ Variabel } & \multicolumn{1}{c}{ Pengukuran } \\
\hline Profitabilitas & $\begin{array}{l}\text { ROE adalah ratio Profitabilitas untuk mengukur jumlah laba } \\
\text { bersih tahun berjalan di bandingkan dengan Total Ekuaitas } \\
\text { ROE }=\frac{\text { Laba Bersih }}{\text { Ekuitas }}\end{array}$ \\
\hline $\begin{array}{l}\text { Pertumbuhan } \\
\text { Perusahaan }\end{array}$ & $\begin{array}{l}\text { Growth adalah ratio total aset tahun berjalan dikurangi tahun } \\
\text { sebelumnya dibanding tahun sebelumnya }\end{array}$ \\
& Growth $=\frac{\text { Total Aset } \mathrm{t}-\text { Total Aset } \mathrm{t}-1}{\text { Total Aset } \mathrm{t}-1} \times 100 \%$ \\
\hline Struktur Modal & $\begin{array}{l}\text { DER adalah ratio Struktur Modal untuk mengukur total hutang } \\
\text { (Liabilitas) dibanding dengan total Modal Sendiri }\end{array}$ \\
& DER $=\frac{\text { Total Hutang }}{\text { Total Modal Sendiri }} \times 100 \%$ \\
\hline Return Saham & $\begin{array}{l}\text { Capital gain diukur dari harga penutupan saham tahun sekarang } \\
\text { dikurangi tahun sebelumnya dibanding tahun sebelumnya }\end{array}$ \\
& Capital gain / loss $=\frac{\text { Harga Saham } t-\text { Harga Saham } t-1}{\text { Harga Saham } t-1}$ \\
\hline
\end{tabular}

Sumber: Pengembangan Model, 2021 


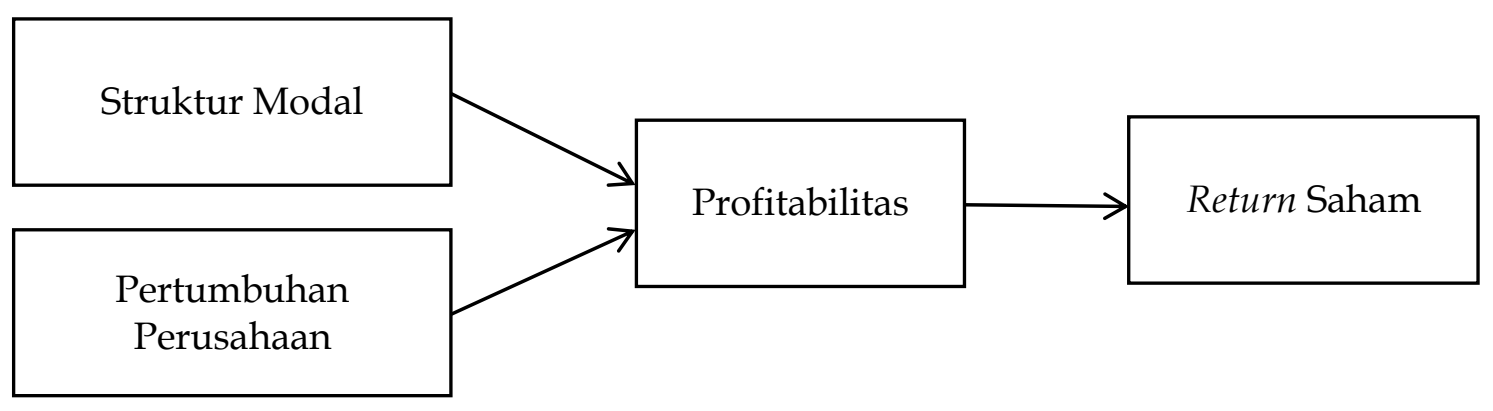

Gambar 1. Kerangka Penelitian

\subsection{Pengumpulan Data}

Data penelitian dari sumber data sekunder yaitu laporan keuangan publik yang telah diaudit dan konsisten terbit selama periode 2017-2019 yang listing di Jakarta Islamic Index (JII). Purposive sampling (Wulandari \& Mulyanto, 2010) untuk pengambilan sampel yaitu dengan kriteria 30 perusahaan dalam daftar perusahaan saham syariah yang menerbitkan laporan keuangan dalam Rupiah. Empat belas perusahaan memenuhi kriteria sebagai sampel.

\subsection{Metode Analisis}

Model struktural digunakan untuk analisis dimana pengolahannya dengan software WarpPLS, yang dapat menunjukkan perkiraan daya antar variabel laten dan evaluasi model pengukuran yang menunjukkan bagaimana variabel manifes mampu menggambarkan variabel laten. Evaluasi Model Fit dengan melihat nilai RSquared, Uji Hipotesis dengan melihat nilai original dan p-value (Jogiyanto, 2018).

\section{Hasil}

\subsection{Statistik Deskriptif}

Total data (n) sampel adalah 42 data. DER memiliki nilai rata-rata paling tinggi dibanding variabel lainnya yaitu 0,861. Rata-rata tertinggi kedua adalah tingkat profitabilitas yaitu sebesar 0,27 atau rata-rata laba $27 \%$. Selanjutnya growth dengan ratarata nilai 0,09 atau $9 \%$, dan return saham dengan rata-rata mengalami penururan sebesar $-0,04$ atau $-4 \%$ (Tabel 3).

Tabel 3. Analisis Statistik Deskriptif

\begin{tabular}{lcccc}
\hline & Min & Max & Average & Std. Dev. \\
\hline Struktur Modal (DER) & 0.01 & 2.91 & 0.86 & 0.64 \\
Pertumbuhan Perusahaan (Growth) & -0.07 & 0.41 & 0.09 & 0.09 \\
Profitabilitas (ROE) & 0.01 & 1.40 & 0.27 & 0.34 \\
Return Saham & -0.80 & 0.75 & -0.04 & 0.28 \\
\cline { 2 - 5 } & \multicolumn{5}{c}{$\mathrm{n}=42$} \\
\hline
\end{tabular}


Sumber: Data penelitian diolah, 2021

\subsection{Uji Model}

Uji Model Fit dilakukan dan diujikan pada 42 data penelitian yang mewakili masingmasing variabel berdasar Tabel 4 .

Tabel 4. Latent Variable Coefficients

\begin{tabular}{lcccc}
\hline & $\begin{array}{c}\text { Pertumbuhan } \\
\text { Perusahaan } \\
\text { (Growth) }\end{array}$ & $\begin{array}{c}\text { Struktur } \\
\text { Modal } \\
\text { (DER) }\end{array}$ & $\begin{array}{c}\text { Profitabilitas } \\
\text { (ROE) }\end{array}$ & $\begin{array}{c}\text { Return } \\
\text { Saham }\end{array}$ \\
\hline R-Squared & 0.70 & & & 0.13 \\
Adj. R-Squared & 0.68 & & & 0.11 \\
\hline
\end{tabular}

Sumber: Data penelitian diolah, 2021

Hasil uji menunjukkan nilai R-square $\left(\mathrm{R}^{2}\right)$ variabel independen terhadap profitabiltias sebesar 0,70 yang berarti 70\% variasi profitabilitas dapat dijelaskan struktur modal dan pertumbuhan. Sementara nilai R-square $\left(\mathrm{R}^{2}\right)$ profitabilitas terhadap return saham hanya sebesar 0,13 yang berarti hanya 13\% variabel intervering dapat menjelaskan variasi variabel dependennya dalam hal ini profitabilitas terhadap return atau pengembalian saham. Meskipun memiliki nilai $\mathrm{R}^{2}$ yang kecil pada return saham sebesar $13 \%$, hasil evaluasi model fit dan quality indicesmenunjukkan bahwa model penelitian dapat dikatakan "Ideal" karena telah memenuhi syarat uji (Tabel 5).

Tabel 5. Pengujian Model

\begin{tabular}{|c|c|c|c|}
\hline Elemen Model & Indeks & p-value & Kriteria \\
\hline APC & 0.410 & $\mathrm{P}<0.001$ & $\mathrm{P}<0.05$ \\
\hline ARS & 0.412 & $\mathrm{P}<0.001$ & $\mathrm{P}<0.05$ \\
\hline AARS & 0.393 & $P<0.001$ & $\mathrm{P}<0.05$ \\
\hline AVIF & 1.032 & \multicolumn{2}{|c|}{$\leq 5$; ideal $\leq 3.3$} \\
\hline RSCR & 1.000 & \multicolumn{2}{|c|}{$\geq 0.9 ;$ ideal $=1$} \\
\hline AFVIF & 1.620 & \multicolumn{2}{|c|}{$\leq 5$; ideal $\leq 3.3$} \\
\hline SPR & 1.000 & \multicolumn{2}{|c|}{$\geq 0.7$; ideal $=1$} \\
\hline GoF & 0.642 & \multicolumn{2}{|c|}{ Rendah $\geq 0.1$, Sedang $\geq 0.25$, Tinggi $\geq 0.36$} \\
\hline
\end{tabular}

Sumber: Data penelitian diolah, 2021

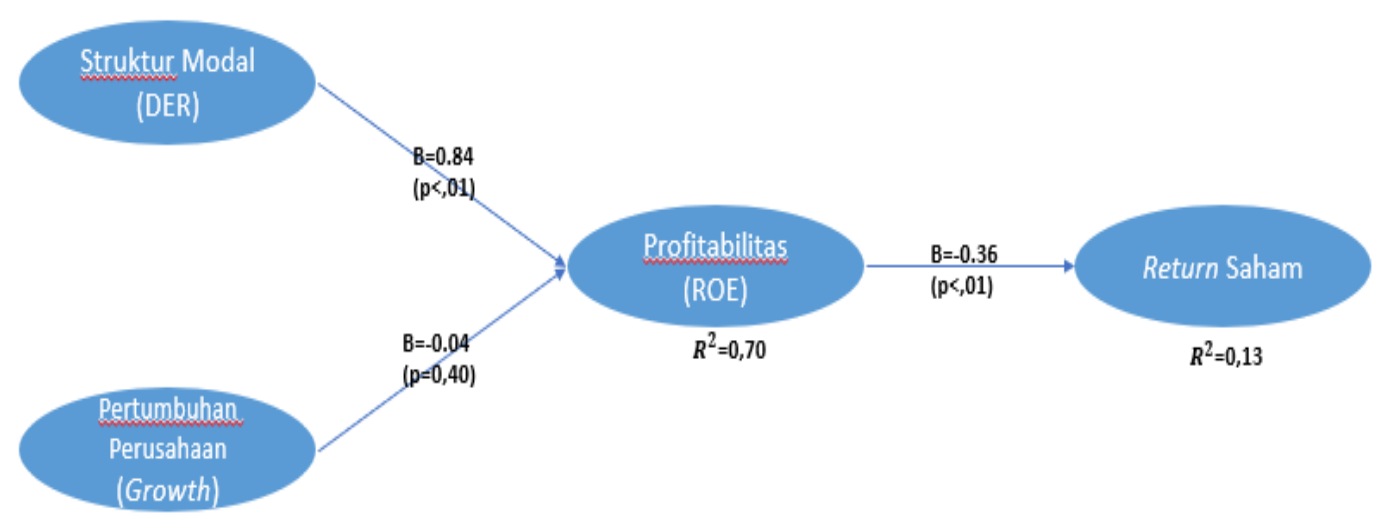

Sumber: Data sekunder yang diolah dari WrapPLS 2021

“LPPM Universitas Pelita Bangsa" 
Gambar 2. Hasil Analisis

\subsection{Uji Hipotesis}

Tabel 6. Path Coefficient

\begin{tabular}{lcccc}
\hline \multicolumn{1}{c}{ Dirrect Effect } & $\begin{array}{c}\text { Original } \\
\text { Sampel }\end{array}$ & P-Value & Hipotesis & Hasil Uji \\
\hline ROE $\rightarrow$ Return Saham & -0.36 & 0.01 & Berpengaruh & Signifikan \\
DER $\rightarrow$ ROE & 0.84 & 0.00 & Berpengaruh & Signifikan \\
Growth $\rightarrow$ ROE & -0.04 & 0.40 & Berpengaruh & Tidak Signifikan \\
\hline Indirrect Effect & Original & P-Value & Hipotesis & Hasil Uji \\
\hline DER $\rightarrow$ ROE $\rightarrow$ Return Saham & -0.30 & 0.00 & Berpengaruh & Signifikan \\
Growth $\rightarrow$ ROE $\rightarrow$ Return Saham & 0.01 & 0.46 & Berpengaruh & Tidak Signifikan \\
\hline
\end{tabular}

Sumber: Data diolah, 2021

Profitabiltas terhadap return saham signifikan dengan memiliki nilai original $(\beta)-0,36$ dan p-value $0,01<0.05$; yang menunjukkan $\mathrm{H} 1$ diterima, profitabilitas berpengaruh signifikan dengan arah negatif terhadap return saham. Pengaruh struktur modal terhadap profitabilitas memiliki nilai original $(\beta)$ 0,836 dengan p-value lebih kecil dari taraf uji $(0,001<0,05)$ sehingga berpengaruh positif signifikan artinya $\mathrm{H} 2$ diterima. Struktur modal terhadap return saham dimediasi profitabilitas memiliki nilai original ( $\beta$ ) 0,30 dan p-value 0,00<0,00 memungkinkan profitabilitas memediasi struktur modal dan return saham sehingga $\mathrm{H} 3$ diterima. Pengaruh pertumbuhan perusahaan terhadap profitabilitas memiliki nilai original $(\beta)-0.04$ dan p-value $0,404>0,05$ yang berarti pertumbuhan usaha negatif dan tidak signifikan sehingga $\mathrm{H} 4$ ditolak. Pertumbuhan Perusahan (growth) terhadap return saham dimediasi profitabiltas dengan nilai original ( $\beta$ ) 0,01 dan p-value 0,46>0,05 yang artinya tidak signifikan sehingga $\mathrm{H} 5$ ditolak.

\section{Pembahasan}

\subsection{Pengaruh Profitabilitas terhadap Return Saham}

Profitabilitas mempengaruhi return saham secara negatif. ROE tidak mendapat respon positif dari pelaku pasar modal, tetapi cenderung direspon negatif. Hasil ini serupa dengan yang lain (Subeakti \& Taufik, 2009; D \& Rangga, 2009) dimana ROE tidak berdampak pada return saham. Namun penelitian ini berlawanan dengan penelitian sebelumnya (Mariani et al., 2016; Michael \& Pizzica, 2014) dimana profitabilitas mempengaruhi pengembalian saham secara positif.

Pengaruh negatif profitabilitas terhadap return saham terjadi karena model distribusi return saham yang cenderung menurun seiring dengan peningkatan ROE. Rata-rata kenaikan keuntungan perusahaan syariah yang hanya $25,7 \%$ tidak sebanding dengan pertumbuhan utang sebesar 86\% dari 2017- 2019 sehingga minat berinvestasi investor pada saham syariah menurun dan cenderung menurunkan trend return saham.

\subsection{Pengaruh Struktur Modal Terhadap Profitabilitas dan Return Saham}


Struktur modal berpengaruh dengan arah positif terhadap Profitabilitas sebesar 0,836. Semakin tinggi banyak modal perusahaan yang berasal dari hutang akan meningkatkan pendapatan bersih. Penelitian ini tidak sejalan dengan temuan sebelumnya (Aprillia \& Mohammad, 2020). DER yang tinggi menunjukkan lebih banyak hutang yang digunakan untuk membiaya kegiatan perusahaan. Pengaruh positif menunjukkan bahwa semakin banyak modal yang berasal dari hutang akan meningkatkan kemampuan perusahaan menghasilkan laba. Dengan kata lain, untuk mendapatkan laba yang tinggi maka perusahaan syariah hendaknya lebih banyak menggunakan hutang dalam membiaya operasional perusahaan.

Hasil pengujian indirect effect menunjukkan profitabilitas (ROE) dapat memediasi struktur modal (DER) terhadap return saham dengan arah negatif. Modal yang mayoritas berasal dari hutang akan meningkatkan keuntungan perusahaan tetapi pada akhirnya justru menurunkan return saham. Laba yang tinggi mengurangi penggunaan dana eksternal. Laba yang diperoleh mampu menyediakan dana internal yang besar untuk mendanai aktivitas operasional perusahaan sehingga dapat menurunkan penggunaan akan dana eksternal sehingga akhirnya akan meningkatkan nilai return saham (Wiyani, 2017; Mariani et al., 2016).

\subsection{Pengaruh Pertumbuhan Perusahaan Terhadap Profitabilitasdan Return Saham}

Pertumbuhan perusahaan diukur menggunakan perubahan total aset perusahaan. Pertumbuhan perusahaan tidak mampu mendorong keuntungan perusahaan. Kondisi ini berbeda dengan penelitian lain (Susana \& Achyani Fatchan, 2006; Jason et al., 2005) yang hasilnya pertumbuhan signifikan dan konsisten mempengaruhi profitabilitas. Penelitian ini sejalan dengan sebelumnya (Cyrus et al., 2001) yang menghasilkan temuan bahwa memaksimalkan pertumbuhan belum tentu memaksimalkan keuntungan.

Pengujian berikutnya menemukan bahwa profitabilitas tidak terbukti dapat memediasi pengaruh pertumbuhan perusahaan (growth) terhadap return saham. Temuan penelitian ini berbeda dengan sebelumnya (Cyrus et al., 2001; Jason et al., 2005; Susana \& Achyani Fatchan, 2006; Estika, 2013). Selama periode penelitian, rata-rata pertumbuhan perusahaan syariah cenderung menurun meskipun ada pertumbuhan laba sebesar 25,7\%. Nilai tersebut berarti belum mampu digunakan untuk meningkatkan laba perusahaan. Perusahaan hendaknya menginvestasikan laba yang diperolehnya untuk kegiatan operasional dibanding memperbesar asetnya.

\section{Kesimpulan}

Profitabilitas mampu memediasi struktur modal terhadap return saham dimana profitabilitas dipengaruhi secara positif oleh struktur modal dan mempengaruhi return saham secara negatif. Profitabilitas tidak mampu memediasi pertumbuhan perusahaan terhadap return saham dimana pertumbuhan aset tidak mempengaruhi laba perusahaan.

Penelitian lanjutan hendaknya dapat dilakukan dengan sampel, periode, dan cakupan yang lebih luas. Penambahan variabel dari faktor internal dan eksternal perusahaaan juga perlu dipertimbangkan. 


\section{Daftar Pustaka}

Agus, S. (2010). Manajemen Keuangan Teori dan Aplikasi Edisi Empat (Empat). BPFE.

Aini, N., Susilowati, Y., Murdianto, A., \& Wulandari, P. (2020). Pengaruh Return on Asset, Current Ratio , Debt To Equity Ratio , Dan Pertumbuhan Aset Terhadap Return Saham ( Studi Kasus Pada Perusahaan Pertambangan Yang Terdaftar Di BEI Tahun 2015-2017). Proceeding SENDIU, 1997, 661-668. https://unisbank.ac.id/ojs/index.php/sendi_u/article/view/8050/3019.

Aprillia, S. Z., \& Mohammad, G. (2020). Dampak Modal Kerja, Struktur Modal, Struktur Aset, Likuiditas, Dan Pertumbuhan Perusahaan Terhadap Profitabilitas. National Conference for Ummah.

Arista, D. A. (2016). ANALISIS FAKTOR-FAKTOR YANG MEMPENGARUHI RETURN SAHAM. E-Jurnal Manajemen Universitas Udayana.

Asmirantho, E., Mulya, Y., \& Firmansyah, D. A. (2016). PENGARUH KINERJA KEUANGAN DAN MAKROEKONOMI TERHADAP RETURN SAHAM PADA SUBSEKTOR MAKANAN DAN MINUMAN PERIODE 2011-2015. JIMFE (Jurnal Ilmiah Manajemen Fakultas Ekonomi). https:// doi.org/10.34203/jimfe.v2i2.445

Carlo, M. A. (2014). Pengaruh Return on Equity, Dividend Payout Ratio, Dan Price To Earnings Ratio Pada Return Saham. E-Jurnal Akuntansi Universitas Udayana, 7(1), 151-164.

Cyrus, R., Luc, S. A., \& Alan, J. R. (2001). Growth, Corporate Profitability, and Value Creation. Financial Analysts Journal, 58(6).

D, H. A., \& Rangga, A. (2009). Analisis Pengaruh Kinerja Keuangan dan Return Saham di Bursa Efek Indonesia. 7(1), 13-21.

Dwi, M., Mulyono, \& Rahfiani, K. (2009). The Effect of financial ratios, firm size, and cash flow from operataing activities in the interim report to the stsock return. Chinese Business Review, 8, 44-55.

Eduardus Tandelilin. (2010). Portofolio dan Invstasi (1st ed.). Kanisius.

Eni, M. (2016). ANALISIS PROFITABILITAS, PERTUMBUHAN PERUSAHAAN, PERTUMBUHAN PENJUALAN DAN STRUKTUR AKTIVA TERHADAP STRUKTUR MODAL PADA PERUSAHAAN SEKTOR INDUSTRI BARANG KONSUMSI YANG TERDAFTAR DI BURSA EFEK INDONESIA. Riset Akutansi Dan KeuangaN INDONESIA, 1(2), 143-151.

Estika, P. M. (2013). ANALISIS PENGARUH RETURN ON ASSET, DEBT TO EQUITY RATIO, FIRM SIZE, GROWTH dan FREE CASH FLOW TERHADAP DEVIDEN PAYOUT RATIO.

Eugene, B. F., \& Houston F Joel. (2009). Fundamentals of Financial Management (12th Editi). Mason: South-Westtern Cengage Learning.

Firdausia, S. (2021). Pengaruh Return On Asset, Market Value Added dan Debt To Equity Ratio Terhadap Return Saham Syariah. Jurnal Indonesia Sosial Teknologi. https:// doi.org/10.36418/jist.v2i4.131

Fitriana, D., Oemar, A., \& Andini, R. (2016). Pengaruh Likuiditas, Solvabilitas,Profitabilitas, Aktivitas dan Kebijakan Dividen Terhadap Return Saham Perusahaan Pertambangan Yang Terdaftar Pada Bei Periode 2007-2013. Journal Of Accounting. 
Franco, M., \& Merton, M. H. (1958). The Cost Of Capital, Corporation Finance And The Theory Of Investment. JSTOR, 48(3), 261-297.

IDX SYARIAH. (n.d.). https:/ / www.idx.co.id/idx-syariah/

Indah Puspitadewi, C., \& Rahyuda, H. (2016). Pengaruh Der, Roa, Per Dan Eva Terhadap Return Saham Pada Perusahaan Food and Beverage Di Bei. E-Jurnal Manajemen Universitas Udayana, 5(3), 253567.

Jason, F. R., Paul, S., \& Evan, D. J. (2005). GROWTH AND PROFITABILITY IN SMALL AND MEDIUM SIZED AUSTRALIAN FIRMS. AGSE Entrepreneurship Exchange.

Jogiyanto, H. (2018). METODA PENGUMPULAN DAN TEKNIK ANALISIS DATA. ANDI (Anggota IKAPI).

JONI, \& LINA. (2010). FAKTOR-FAKTOR YANG MEMPENGARUHI STRUKTUR MODAL. BISNIS DAN AKUTANSI, 12(2), 82-97.

Kasmir. (2011). Analisis Laporan Keuangan. Raja Grafindo Persada.

Komparatif, S., Perusahaan, P., \& Bullish, P. (2006). Growth Opportunities, Return on Asset Dan Debt To Equity Ratio Terhadap Return Saham. Tesis.

Mariani, W. E., Rasmini, N. K., \& Mimba, N. P. S. H. (2016). Kemampuan Good Corporate Governance dan CSR Memoderasi Pengaruh Likuiditas, Solvabilitas, dan Profitabilitas Pada Nilai Perusahaan. E-Jurnal Ekonomi Dan Bisnis Universitas Udayana, 5(9), 2801-2836.

Michael, \& Pizzica, J. A. (2014). Financial Ratios for Executives: How to Assess Company Strength, Fix Problems, and Make Better Decisions. Apress.

Mulyanto, H. \& Wulandari, A. (2010). Penelitian Metode \& Analisis. Semarang. CV.Agung. Natarsyah, S. (2000). Analisis Pengaruh Beberapa Faktor Fundamental dan Risiko Sistematik Terhadap Harga Saham Kasus Industri Barang Konsumsi Yang GoPublik di Pasar Modal Indonesia. Jurnal Ekonomi Dan Bisnis Indonesia.

Nurkharomi, L. F. ., Nurdin, \& Azib. (2017). Pengaruh Pertumbuhan Perusahaan dan Agency Cost terhadap Return Saham ( Studi Kasus pada Perusahaan LQ45 Periode 2013-2015 ). Manajemen, Prodi, 3 no.1, 548-554.

Pandaya, P., Julianti, P. D., \& Suprapta, I. (2020). PENGARUH FAKTOR FUNDAMENTAL TERHADAP RETURN SAHAM. JURNAL AKUNTANSI. https://doi.org/10.37932/ja.v9i2.156

Pranata dkk. (2013). No 主観的健康感を中心とした在宅高齢者における 健康関連指標に 関する共分散構造分析Title. 10(1), 13-28.

Purwanti, Y. D., \& Nurastuti, P. (2020). Pengaruh Analisis Fundamental Dan Risiko Sistematik Terhadap Harga Saham Pada Pasar Modal Syariah. EKOMABIS: Jurnal Ekonomi Manajemen Bisnis.

Rr, S. (2011). Pengaruh Pertumbuhan Aktiva Dan Ukuran Perusahaan Terhadap Struktur Modal Pada Perusahaan Perbankan. MEDIA EKONOMI DAN MANAJEMEN, 24(2), 81-92.

Samsul, M. (2006). Pasar Modal Dan Manajemen Portofolio. Erlangga.

Solechan, A., \& Setiawati, I. (2009). Pengaruh Karakteristik Sistem Akuntansi Manajemen dan Desentralisasi sebagai Variabel Moderating Terhadap Kinerja Manajerial (Studi Empiris Perusahaan Manufaktur di Kabupaten Semarang). Journal of Biomedical Informatics. 
Subeakti, H. S., \& Taufik, A. (2009). The effect of financial ratios, firm size, and cash flow from operating activities in the interim report to the stock return. Chinese Business Review. https:/ / doi.org/10.17265/1537-1506/2009.06.005

Subramanyam, K. R., \& John, W. J. (2014). Analisi Laporan Keuangan (Y. DEWI (Ed.)). Salemba Empat.

Sugiarto, A. (2012). Analisa Pengaruh Beta, Size Perusahaan, Der Dan Pbv Ratio Terhadap Return Saham. Jurnal Dinamika Akuntansi, 3(1), 8-14. https://doi.org/10.15294/jda.v3i1.1939

Susana, D., \& Achyani Fatchan. (2006). ANALISIS PENGARUH INVESTASI, LIKUDITAS, PROFITABILITAS, PERTUMBUHAN PERUSAHAAN TERHADAP KEBIJAKAN DEVIDEN PAYOUT RATIO. Akutansi Dan Keuangan, 5, 51-62.

Trisnawati, I. T. A. (2009). Pengaruh economic value added, arus kas operasi, residual income, earnigns, operating leverage dan market value added terhadap return saham. Jurnal Bisnis Dan Akuntansi.

Widodo, S. (2007). Analisis Pengaruh Rasio Aktivitas, Rasio Profitabilitas, Dan Rasio Pasar, Terhadap Return Saham Syariah Dalam Kelompok Jakarta Islamic Index (Jii) Tahun 2003 - 2005. Universitas Diponegoro.

Wiyani, L. D. W. N. T. (2017). Pengaruh Debt To Equity Ratio, Firm Size, Inventory Turnover, Assets Turnover dan Pertumbuhan Penjualan terhadap Profitabilitas (Studi Kasus pada Industri Makanan dan Minuman yang Terdaftar di BEI Periode 2011-2015). Jurnal Online Insan Akuntan, 2(1), 234099. 